\title{
Heterosis and Gene Action for Yield and Quality Traits in Cucumber (Cucumis sativus L.)
}

\author{
K. Rajaguru ${ }^{1 *}$, T. Arumugam², D. Sassi kumar ${ }^{3}$, S. Jeeva ${ }^{4}$, \\ R. Baskaran ${ }^{5}$ and A. Baskaran ${ }^{6}$
}

${ }^{1}$ Department of vegetable crops, Horticultural College and Research Institute, Tamilnadu Agricultural University, Coimbatore, India ${ }^{2}$ Horticultural College and Research Institute, Periyakulam, India

${ }^{3}$ Tamilnadu Rice Research Institute, Aduthurai, India

${ }^{4}$ Horticultural College and Research Institute for Women, Trichy, India

${ }^{5}$ Agricultural College and Research Institute, Eachangkottai, Thanjavur, India

${ }^{6}$ Agricultural College and Research Institute, Vazhavachanur, Thiruvannamalai, India

*Corresponding author

\section{A B S T R A C T}

Keywords

Cucumber,

Heterosis, Gene

action, Parents and

hybrids

\section{Article Info}

Accepted:

12 September 2019

Available Online:

10 October 2019
The present investigation were carried out understand heterosis and gene action for yield and quality traits in cucumber genotypes. The materials consist of three lines and four testers and the resultant 12 hybrids through Line $x$ Tester mating design. The present estimation of heterosis identified that L2XT2 (Koradacherry local x Orathanadu local) being the superior hybrid for most of the traits by expressing higher significance Relative Heterosis, Heterobeltiosis and Standard Heterosis. The gene action reveals that the ratio for all the traits expressed less than 1 indicates the nonadditive gene action. The proportional contribution was higher in Lines $x$ Testers interaction than lines and testers.

\section{Introduction}

Cucumber (Cucumis sativus L.) is a member of the family Cucurbitaceae, which comprises of 117 genera and 825 species grown in warmer parts of the world (Gopalakrishnan 2007). The fruit is also used as an astringent and antipyretic. Despite being native of India and having sufficient genetic variability, very meagre work has been done for the improvement of this crop.

Heterosis or hybrid vigor can play a vital role in increasing the yield quality of cucumber. It refers to the phenomenon in which F1 hybrid obtained by crossing of two genetically 
dissimilar inbred lines or genotypes, shows increased or decreased vigor over the better parent or mid parent value (Poehlman, 1979). In cucurbits, heterosis was first noted by Hays and Jones (Hays et al., 1961).

Now a day's heterosis breeding is one of the efficient tools to exploit the heterotic response for several traits. Very few research works relating to heterosis of cucumber have been conducted in Bangladesh.

So, intensive research efforts are needed in several areas, particularly, selection of superior genotypes. There is a lot of variability among the existing cucumber germplasm of tamilnadu area; in order to develop a better hybrid with these available genotypes the present research was carried out.

\section{Materials and Methods}

The present investigation was carried out at ICAR - Krishi vigyan Kendra, Needamangalam, Tiruvarur district of Tamilnadu. The soil is clay loam with neutral $\mathrm{pH}$.

The present material comprised of seven parents (three lines and four testers) involving twelve hybrid combination were used for the study (Table 1). Trial is conducted in the Kharif season, 2018 (By sowing on $21^{\text {st }}$ May) and recorded Maximum $37^{\circ} \mathrm{C}$ and Minimum $27^{\circ} \mathrm{C}$ with $60.80 \mathrm{~mm}$ rainfall during the cropping period. Relative humidity was recorded as Maximum $70 \%$ and minimum $46 \%$ in the experimental location. The observations were carried out on fourteen important yield and quality traits of cucumber. Crosses were attempted as per line $\mathrm{x}$ tester design suggested by Kempthorne (1957). TNAUSTAT statistical package for $\mathrm{Lx} T$ analysis with parents were used for statistical analysis.

\section{Results and Discussion}

\section{Heterosis}

Among the fourteen different characters taken for the investigation with twelve hybrid combination, only four important characters for earliness (days to first female flower anthesis), Yield (Number of fruits per vine and Total marketable fruit yield per vine), Quality (Total soluble solids) were taken for the discussion here and results are presented in Table 2. Earliness indicates the negative estimation of heterosis and it is one of the prime objectives of any plant breeding programme to get the produce at the earlier time. The parent L1 (33.20) showed earliness for female flower anthesis. Similarly hybrid L1xT2 (32.20) exhibited earliness in female flower anthesis. The crosses L3xT4 (-19.41), L2xT2 (-15.47) and L3xT1(-10.44) exhibited negative significant relative heterosis for days to first female flower anthesis. The crosses L3xT4 (-20.87) followed by L2xT2 (-18.97) and L3xT3 (-16.93) showed negative heterobeltiosis for this trait. Similar results were recorded by Dogra et al., (1997), Vijay Kumara et al., (1993) and Pandey et al., (2005) for the earliness trait nodal position of first female flower in cucumber.

For number of fruits per plant, parent L1 (12.75) and hybrid L1xT2 (15.50) expressed maximum mean performance. For this trait the positive significance relative heterosis is observed in L3xT1 (38.15), L2xT3 (33.54) and L2xT2 (31.28). Same crosses recorded the heterobeltiosis with positive and significant values of $32.55,30.64$ and 26.81.The important fruit yield deciding character total marketable fruit yield per vine recorded significant positive relative heterosis in seven hybrids and maximum heterosis is observed in L2xT3 (50.31), the positive heterobeltiosis recorded in six hybrid out of twelve hybrids and the maximum is recorded in the cross 
L2xT2 (69.16) and the same condition is prevailed in standard heterosis with the maximum value of 42.22 from L2xT2.

Like earliness and yield, quality is the major deciding factor for produce to fetch good price in the market. The positive heterosis indicates the desirable one for total soluble solids (TSS). It was recorded maximum TSS in T3 (3.59) parent and L2xT2 hybrid (4.12). Eight, four and ten hybrids expressed positive and significant heterosis for TSS in Relative heterosis, heterobeltiosis and standard heterosis. L3xT1 (48.49) for relative heterosis, L2xT2 (25.04 and 72.75) expressed highest heterosis among the twelve hybrids.

\section{Gene action}

The estimates of genetic components of variance facilitate to adopt suitable breeding methodology for the purposeful management of generated variability for traits under genetic improvement (Cockerham, 1961 and Sprague, 1966). On various mating designs adopted for this purpose, line $\mathrm{x}$ tester not only evaluates parents and crosses for combining ability, but also provides the information on nature of gene action controlling the traits under consideration. In the present study the estimates of $\sigma^{2}$ sca were higher in magnitude as compared to $\sigma^{2}$ gca (average) for all the traits indicating the predominant role of non additive gene action governing these traits (Table 3). Similar finding were also reported by Singh et al., (1973), Bhateria et al., (1995), Kumar and Kumar (2017).

In our study variance ratio was found less than one for all the traits viz., vine length $(-0.01)$, days to first male flower anthesis (0.04), days to first female flower anthesis (-0.02), number of primary branches per vine $(-0.03)$, days to first harvest (-0.01), fruit length (0.02), fruit weight (0.07), flesh thickness (0.01), fruit diameter $(0.60)$, number of fruits per vine ($0.01)$, Marketable fruit yield per vine (0.01), Total soluble solids (0.05), Ascorbic acid (0.04) and Total chlorophyll content (0.03). The variance ratio were also found lesser than $1\left(\sigma^{2} \mathrm{~g} / \sigma^{2} \mathrm{~s}\right)$ for all the traits and again it confirms importance of non additive gene action. The results are in accordance with earlier study of several workers in cucumber (Sharma et al., 2000; Singh and Sharma, 2006; Munshi et al., 2006; Yadav et al., 2007; Dogra and Kanwar, 2011; Kumar et al., 2011).

Table.1 List of cucumber genotypes used in this study

\begin{tabular}{|c|c|c|}
\hline S.No. & Genotype & Source \\
\hline \multicolumn{1}{|c|}{ Lines } & \\
\hline $\mathbf{1}$ & L1 - Amaravathi & Thanjavur, Tamilnadu \\
\hline $\mathbf{2}$ & L2- Koradacherry & Tiruvarur, Tamilnadu \\
\hline $\mathbf{3}$ & L3- Vennamuthupatti & Pudhukottai, Tamilnadu \\
\hline \multicolumn{2}{|c|}{ Testers } \\
\hline $\mathbf{1}$ & T1- Kattur & Thanjavur, Tamilnadu \\
\hline $\mathbf{2}$ & T2-Orathanadu & Thanjavur, Tamilnadu \\
\hline $\mathbf{3}$ & T3-Aipatti & Pudhukottai, Tamilnadu \\
\hline $\mathbf{4}$ & T4-Periyakollapatti & Virudhunagar, Tamilnadu \\
\hline
\end{tabular}


Table.2 Estimation of Relative Heterosis (RH), Heterobeltiosis (HB) and Standard Heterosis (SH) for earliness, yield and quality traits of Cucumber

\begin{tabular}{|c|c|c|c|c|c|c|c|c|c|c|c|c|}
\hline \multirow[t]{2}{*}{ CROSS } & \multicolumn{3}{|c|}{$\begin{array}{c}\text { Days to first female flower } \\
\text { anthesis }\end{array}$} & \multicolumn{3}{|c|}{ Number of fruits per vine } & \multicolumn{3}{|c|}{$\begin{array}{c}\text { Total marketable fruit yield per } \\
\text { vine }\end{array}$} & \multicolumn{3}{|c|}{ Total soluble solids } \\
\hline & RH & RH & RH & RH & HB & SH & RH & HB & SH & RH & HB & SH \\
\hline L1 x T1 & $12.06 * *$ & -4.56 & $35.69 * *$ & $12.86 *$ & -3.96 & -3.96 & $16.57 *$ & -9.44 & -9.44 & $15.50 * *$ & 1.76 & $33.54 * *$ \\
\hline $\mathbf{L} 1 \times \mathbf{T} 2$ & $-9.80 *$ & $-15.71 * *$ & -3.01 & $30.80 * *$ & $21.57 * *$ & $21.57 * *$ & $45.99 * *$ & $33.15 * *$ & $33.15 * *$ & $41.37 * *$ & $21.85 * *$ & $68.34 * *$ \\
\hline L1 $\times$ T3 & $14.62 * *$ & 4.46 & $26.96 * *$ & -5.34 & $-10.94 *$ & $-10.94 *$ & $-22.33 * *$ & $-24.63 * *$ & $-24.63 * *$ & $16.49 * *$ & -3.06 & $45.91 * *$ \\
\hline L1 x T4 & $17.84 * *$ & 1.08 & $41.27 * *$ & -6.03 & $-19.06 * *$ & $-19.06 * *$ & 0.34 & $-18.15 * *$ & $-18.15 * *$ & 4.07 & -5.17 & $15.30 *$ \\
\hline L2 $\times$ T1 & -2.87 & $-8.58 *$ & $29.97 * *$ & -5.70 & $-16.94 * *$ & $-23.45 * *$ & -1.73 & $-18.50 *$ & $-31.48 * *$ & -2.92 & -4.31 & $25.58 * *$ \\
\hline $\mathrm{L} 2 \times \mathrm{T} 2$ & $-15.47 * *$ & $-18.97 * *$ & 1.66 & $31.28 * *$ & $26.81 * *$ & $16.86 * *$ & $70.86 * *$ & $69.16 * *$ & $42.22 * *$ & $30.07 * *$ & $25.04 * *$ & $72.75 * *$ \\
\hline $\mathrm{L} 2 \times \mathrm{T} 3$ & $-10.24 *$ & $-11.64 *$ & 10.84 & $33.54 * *$ & $30.64 * *$ & $20.39 * *$ & $50.31 * *$ & $42.32 * *$ & $33.89 * *$ & $18.85 * *$ & $9.75 *$ & $65.20 * *$ \\
\hline $\mathrm{L} 2 \times \mathrm{T} 4$ & $9.03 *$ & 3.45 & $44.58 * *$ & -3.70 & $-14.09 *$ & $-20.82 * *$ & -2.64 & $-14.76 *$ & $-28.33 * *$ & $-15.32 * *$ & $-17.27 * *$ & 5.45 \\
\hline L3 x T1 & $-10.44 * *$ & $-11.32 *$ & $28.61 * *$ & $38.15 * *$ & $32.55 * *$ & 1.25 & $29.83 * *$ & $20.69 *$ & $-22.22 * *$ & $48.49 * *$ & $22.04 * *$ & $60.17 * *$ \\
\hline L3 x T2 & 5.50 & -5.40 & $37.20 * *$ & -2.37 & -7.76 & $-20.78 * *$ & 14.25 & 1.80 & $-16.11 *$ & $12.81 *$ & -9.10 & $25.58 * *$ \\
\hline L3 x T3 & $-9.60 *$ & $-16.93 * *$ & $20.48 * *$ & 8.91 & 1.65 & $-10.39 *$ & $15.65 *$ & -2.56 & -8.33 & $35.41 * *$ & 5.71 & $59.12 * *$ \\
\hline L3 x T4 & $-19.41 * *$ & $-20.87 * *$ & $14.76 *$ & $14.48 *$ & 11.40 & $-14.90 * *$ & $47.17 * *$ & $45.69 * *$ & -6.11 & 8.04 & -8.45 & 11.32 \\
\hline
\end{tabular}


Table.3 Estimates of genetic component of variance for yield and quality traits in cucumber

\begin{tabular}{|c|c|c|c|c|c|c|c|c|}
\hline S.No. & Characters & $\begin{array}{l}\sigma^{2} \mathrm{GCA} \\
\text { (Lines) }\end{array}$ & $\begin{array}{c}\sigma^{2} \mathbf{G C A} \\
\text { (Testers) }\end{array}$ & $\begin{array}{c}\sigma^{2} \mathrm{GCA} \\
\text { (Average) }\end{array}$ & $\sigma^{2} \mathrm{SCA}$ & $\sigma^{2} g$ & $\sigma^{2} s$ & $\begin{array}{c}\sigma^{2} g / \sigma^{2} s \\
\text { (variance } \\
\text { ratio) }\end{array}$ \\
\hline 1 & Vine length & -13.31 & -3.40 & -1.61 & 167.32 & -1.61 & 187.93 & -0.01 \\
\hline 2 & Days to first male flower anthesis & -1.05 & 3.63 & 0.28 & 9.23 & 0.28 & 7.09 & 0.04 \\
\hline 3 & Days to first female flower anthesis & -7.03 & 1.49 & -0.50 & 20.41 & -0.50 & 28.13 & -0.02 \\
\hline 4 & Number of primary branches per vine & -0.26 & -0.23 & -0.04 & 0.76 & -0.04 & 1.33 & -0.03 \\
\hline 5 & Days to first harvest & -9.20 & 3.47 & -0.49 & 29.03 & -0.49 & 37.66 & -0.01 \\
\hline 6 & Fruit length & 2.31 & 0.42 & 0.26 & 16.78 & 0.26 & 13.36 & 0.02 \\
\hline 7 & Fruit weight & -95.61 & 363.75 & 29.51 & 678.43 & 29.51 & 452.07 & 0.07 \\
\hline 8 & Flesh thickness & -0.0009 & 0.0065 & 0.0006 & 0.07 & 0.0006 & 0.07 & 0.01 \\
\hline 9 & Fruit diameter & 0.08 & 0.48 & 0.06 & 0.69 & 0.06 & 0.10 & 0.60 \\
\hline 10 & Number of fruits per vine & -0.84 & 0.09 & -0.06 & 3.84 & -0.06 & 4.84 & -0.01 \\
\hline 11 & Total marketable fruit yield per vine & -0.05 & 0.10 & 0.005 & 0.46 & 0.005 & 0.43 & 0.01 \\
\hline 12 & Total soluble solids & -0.05 & 0.19 & 0.01 & 0.31 & 0.01 & 0.19 & 0.05 \\
\hline 13 & Ascorbic acid & 0.009 & 0.17 & 0.01 & 0.46 & 0.01 & 0.28 & 0.04 \\
\hline 14 & Total chlorophyll content & 0.009 & 0.009 & 0.001 & 0.05 & 0.001 & 0.03 & 0.03 \\
\hline
\end{tabular}


Table.4 Proportional contribution of lines, testers and their interactions to total variance

\begin{tabular}{|c|c|c|c|c|}
\hline S.No. & Characters & Line(s) & Tester(s) & $\begin{array}{c}\text { Lines x } \\
\text { Testers }\end{array}$ \\
\hline $\mathbf{1}$ & Vine length & 14.07 & 27.61 & 58.32 \\
\hline $\mathbf{2}$ & Days to first male flower anthesis & 5.94 & 52.18 & 41.88 \\
\hline $\mathbf{3}$ & Days to first female flower anthesis & 1.25 & 36.05 & 62.70 \\
\hline $\mathbf{4}$ & Number of primary branches per vine & 6.76 & 19.60 & 73.64 \\
\hline $\mathbf{5}$ & Days to first harvest & 0.92 & 38.49 & 60.60 \\
\hline $\mathbf{6}$ & Fruit length & 26.32 & 25.99 & 47.69 \\
\hline $\mathbf{7}$ & Fruit weight & 2.83 & 59.83 & 37.34 \\
\hline $\mathbf{8}$ & Flesh thickness & 16.37 & 32.12 & 51.51 \\
\hline $\mathbf{9}$ & Fruit diameter & 14.96 & 72.01 & 13.03 \\
\hline $\mathbf{1 0}$ & Number of fruits per vine & 6.82 & 32.23 & 60.95 \\
\hline $\mathbf{1 1}$ & Total marketable fruit yield per vine & 8.00 & 42.47 & 49.53 \\
\hline $\mathbf{1 2}$ & Total soluble solids & 0.32 & 64.70 & 34.98 \\
\hline $\mathbf{1 3}$ & Ascorbic acid & 13.65 & 49.96 & 36.39 \\
\hline $\mathbf{1 4}$ & Total chlorophyll content & 27.07 & 35.90 & 37.02 \\
\hline
\end{tabular}

Proportional contribution of lines, testers and their interactions

Proportional contribution of lines, testers and their interaction were presented in Table 4. The total variance for the fourteen traits under study shows predominant role of lines $\mathrm{x}$ testers interactions in nine traits viz., number of primary branches per vine (73.64), days to first female flower anthesis (62.70), number of fruits per vine (60.95), days to first harvest (60.60), vine length (58.32), flesh thickness (51.51), Marketable fruit yield per vine (49.53), fruit length (47.69)and total chlorophyll content (37.02) followed by testers for the rest of five traits like fruit diameter (72.01), total soluble solids (64.70), fruit weight (59.83), days to first male flower anthesis (52.18) and ascorbic acid content (49.96). The higher contribution of line $x$ tester interactions than line and testers for the traits indicate higher estimates of specific combining ability variance (Ram et al., 2015). Similar finding are reported by Sharma, 2010.
Based on mean performance among seven parents, L1 expressed highest mean performance for more than 50 percent of the traits including fruit yield per vine. It was followed by L2, T2 and T3. Testers are contributed higher mean value for quality traits. For the hybrid combinations, L2xT2 followed by L1xT2 and L2xT3 showed highest mean performance for various traits.

Estimation of heterosis showed that the hybrid L2xT2 had the highest significant Relative Heterosis, Heterobeltiosis and Standard Heterosis followed by L2xT3, L1XT2.Gene action studies indicated that all the traits are governed by non additive gene action. They can be efficiently improved through heterosis breeding.

The perusal of the data indicated that the estimates of sca were higher in magnitude as compared to gca (average) for all the traits under study, thereby indicating predominant role of non-additive gene action for the traits. 
Further, the variance ratio was found less than one for all the traits in cucumber, again this confirmed the role of non-additive gene action controlling almost all the traits Hence, hybrid vigour could be better exploited for these traits in cucumber. The present study reveals that proportional contribution of lines $\mathrm{x}$ testers interactions was found higher followed by testers and lines.

\section{References}

Airina, C.K., Pradeepkumar, T., George, T.E., Sadhankumar, P.G. and Krishnan, S. 2013, Heterosis breeding exploiting gynoecy in cucumber (Cucumis sativus L.). J. Trop. Agric., 51(1-2): 144-148.

Bhateria S, Chadha C, Thakur SR, Thakur HL. Combining ability and gene action in Brassica juncea L. Himachal Journal of Agricultural Research. 1995; 21(1\&2):17-22.

Cockerham C. 1961 Implications of genetic variances in a hybrid breeding programme. Crop Sci. 1, 47-52.

Dogra BS, Kanwar MS 2011. Exploitation of combining ability in cucumber (Cucumis sativus L.). Research Journal of Agricultural sciences 2(1): 55-59.

Gopalakrishnan TR. 2007. Cucurbits. In: Vegetable Crops. Pp 103

Hays H. K. and D. F. Jones. 1961. First generation crosses in cucumber. Conn Agric ExptSta Ann Rpt: 319-322.

Kempthorne O. 1957. An introduction to Genetic Statistics. John Wiley and Sons, New York, London pp. 458-471

Kumar R and Kumar S, 2017. Usefulness of combining ability and gene action studies for parthenocarpic gynoecious hybrid development in cucumber. Journal of Hill Agriculture 8(2):158165.

Kumar J, Munshi AD, Kumar R, Sureja AK, Sharma RK 2011. Combining ability and its relationship with gene action in slicing cucumber. Indian Journal of Horticulture 68(4): 507-511.

Munshi AD, Kumar R, Panda B 2006. Combining ability in cucumber (Cucumis sativus L.). Indian Journal of Agricultural Sciences 76(12): 750- 752

Poehlman J. M. 1979. Breeding Field Crops. 2nd edition Westport, Connection: The AVI Publishing Company, Inc.

Pandey S, Singh B, Singh M, Rai M. Heterosis in cucumber (Cucumis sativus L.). Veg. Sci. 2005; 32: 143-45.

Ram L, Singh R, Singh SK 2015. Study of combining ability using QPM donors as testers for yield and yield traits in maize (Zea mays L.). SABRAO Journal of Breeding and Genetics 47(2): 99-112.

Sharma AK, Vidyasagar, Pathania NK 2000. Studies on combining ability for earliness and marketable fruit yield in cucumber (Cucumis sativus L.). Himachal Journal of Agricultural Research 26(1 and 2): 54-61.

Sharma M. 2010. Gene action and heterosis studies involving gynoecious lines in cucumber (Cucumis sativus L.). Ph.D. Thesis, Chaudhary Sarwan Kumar Himachal Pradesh Krishi Vishvavidyalaya, Palampur (HP).192p.

Singh RM, Singh HG, Talukdar BS, Chauhan YS, Singh AK. Heterosis in Indian mustard (Brassica juncea L.). Indian Journal of Farm Sciences. 1973; 1(1):15-20.

Singh Y, Sharma S 2006. Combining ability through line $\times$ tester analysis in cucumber (Cucumis sativus L.). Crop Research, Hissar 31(1): 110- 115.

Sprague GF. Quantitative Genetics in plant improvement. In: Plant Breeding: a symposium held at Iowa State University. The Iowa State University Press Ames Iowa. 1966, 315-354.

Vijaykumari P, More TA, Shesadri VS. Heterosis intropical and temperate 
gynoecious hybrids in cucumber. Veg. Sci. 1993; 20:152-57.

Yadav JR, Singh SP, Prihar NS, Yadav JK, Mishra G, Kumar S, Yadav A 2007.
Combining ability for yield and its contributing characters in cucumber (Cucumis sativus L.). Progressive Agriculture (1,2): 116-118.

\section{How to cite this article:}

Rajaguru, K., T. Arumugam, D. Sassi kumar, S. Jeeva, R. Baskaran and Baskaran, A. 2019. Heterosis and Gene Action for Yield and Quality Traits in Cucumber (Cucumis sativus L.). Int.J.Curr.Microbiol.App.Sci. 8(10): 1618-1625. doi: https://doi.org/10.20546/ijcmas.2019.810.189 